\title{
Matematika Sederhana: Fungsi Waktu dalam Pencelupan Biskuit ke dalam Kopi
}

Kita semua pasti pernah makan biskuit, malah ada yang mungkin sering seperti saya, terutama ketika tengah malam. Salah satu cara menikmati biskuit yang bagi saya enak ialah mencelupkannya ke dalam kopi, atau bisa juga tajin, susu, maupun teh, kemudian dimakan. Persis seperti iklan Oreo yang diputar, dijilat, dicelupin, terus diambil Utti. Ketika kita mencelupkan biskuit ke dalam kopi/tajin/susu/teh sebelum dimakan, rasa biskuit bercampur dengan rasa kopi/tajin/susu/teh menghasilkan rasa baru yang lebih enak. Apalagi kalau biskuitnya tanpa selai, seperti biskuit BT BuMil yang saya suka meski lelaki mustahil hamil.

Kalau kita kurang gawean atau ngelilir terus kehabisan rokok kebetulan hujan pula seperti saya sekarang amati dengan seksama dalam tempo waktu yang tak sesingkatnya, ketika biskuit dicelupkan ke dalam minuman di dalam gelas, volume minuman berkurang sejak biskuit mulai dicelupkan. Ini terjadi karena zat cair minuman tersebut masuk ke dalam pori-pori biskuit. Kian lama volume minuman kian berkurang seiring dengan biskuit masih bisa basah menyerap cairan. Namun, suatu saat volume minuman tidak lagi berubah ketika biskuit sudah basah sempurna. Minuman tidak bisa lagi masuk ke dalam biskuit karena semua pori sudah terisi dengan cairan. Ketika saat seperti ini tiba, kita harus waspada dan berhati-hati, sebab keadaan seperti ini bisa membuat harapan makan biskuit celupan sirna karena ambiyar mencampuri minuman.

Dari kegiatan kurang gawean ini kita bisa melihat bahwa volume minuman yang meresap ke dalam biskuit punya hubungan dengan waktu. Punya hubungan dengan sesuatu merupakan pembahasan topik fungsi. Atau dengan tuturan lain: volume minuman yang meresap ke dalam biskuit merupakan fungsi waktu. Mulanya tidak ada zat cair dalam biskuit pada saat akan dicelupkan. Kemudian jumlah zat cair di dalam biskuit makin bertambah seiring berjalannya waktu, dan setelah cukup lama jumlah zat cair tidak lagi berubah. Pertanyaan yang menggelitik adalah adakah persamaan matematika yang menghubungkan volume zat cair yang masuk ke dalam biskuit sebagai fungsi waktu? Ini mungkin persoalan yang tidak serius, tetapi cukup menarik untuk dibahas. Dengan cara itu kita menjadi paham bahwa fenomena yang tidak wah pun bisa dijadikan pembahasan ilmiah yang megah laiknya almarhumah Setiya Utari ketika mengajak bermain seten.

Untuk membangun persamaan, kita bisa menyiapkan hipotesis dahulu. Guna menyingkat penulisan, kita pakai simbol $V_{0}$ untuk volume pori-pori biskuit yang belum dicelupkan. Ketika biskuit sudah dicelupkan, volume pori-pori tersebut disimbolkan dengan $V$. Waktu selama mencelupkan kita sebut saja $t$. Dengan demikian, volume pori-pori yang masih kosong pada saat sembarang $t$ adalah $V_{0}-V$. Kemudian biskuit dicelupkan selama selang waktu $\Delta t$. Pencelupan tersebut menyebabkan ada perubahan volume zat cair $\Delta V$ yang masuk ke dalam biskuit. Berapa besar $\Delta V$ ? Nah, di sinilah kita bisa menyiapkan dua hipotesis berikut:

1. Jumlah zat cair tambahan yang masuk berbanding lurus dengan lama pencelupan, yang dapat disimbolkan:

$\Delta \mathrm{V} \propto \Delta \mathrm{t}$

2. Jumlah zat cair yang masuk berbanding lurus dengan volume pori-pori yang masih kosong, yang dapat disimbolkan:

$\Delta \mathrm{V} \propto \mathrm{V}_{0}-\mathrm{V}$

Menurut Utti, hipotesis ini sangat logis. Ketika volume pori yang kosong masih banyak, kopi dengan mudah meresap ke dalam biskuit atau tambahan zat cair yang masuk besar. Namun, ketika volume pori yang kosong hampir habis, kopi yang masuk juga sedikit. Jika teringat tentang dikat hasil dari dua hipotesis di atas digabung, diperoleh kesebandingan umum berikut:

$$
\Delta \mathrm{V} \propto\left(\mathrm{V}_{0}-\mathrm{V}\right) \Delta \mathrm{t}
$$

Kemudian jika memang masih bisa mulutpun berbicara kesebandingan ini dijadikan sama dengan, kita harus memperkenalkan sebuah tetapan atau konstanta sehingga:

$$
\Delta \mathrm{V}=\mathrm{k}\left(\mathrm{V}_{0}-\mathrm{V}\right) \Delta \mathrm{t}
$$

Jika masih mudah dalam mencari keputusan diambil waktu pencelupan yang sangat singkat, kita menggganti simbol $\Delta$ dengan $d$ sehingga persamaan (4) memiliki bentuk diferensial (saya tidak ikutan cekcok Syekh Newton \& Syekh Leibniz):

$$
\mathrm{dV}=\mathrm{k}\left(\mathrm{V}_{0}-\mathrm{V}\right) \mathrm{dt}
$$


Persamaan (5) harus diselelesaikan tanpa masalah dengan menggunakan syarat awal. Syarat awal, yaitu saat $\mathrm{t}=0$, belum ada kopi yang masuk ke dalam biskuit sehingga $\mathrm{V}=0$. Dengan demikian, persamaan (5) dapat ditulis ulang menjadi:

$$
\frac{d V}{V_{0}-V}=k d t
$$

Kemudian kita lakukan operasi integral ruas kiri dan kanan persamaan (6):

$$
\int \frac{d V}{V_{0}-V}=\int k d t+C
$$

di sini $\mathrm{C}$ adalah konstanta yang akan ditentukan, bukan Chelsea, CL, apalagi Chaeryong. Dengan mudah kita dapatkan:

$$
\begin{aligned}
& -\ln \left(\mathrm{V}_{0}-\mathrm{V}\right) \mathrm{k}=\mathrm{t}+\mathrm{C} \\
& \ln \left(\mathrm{V}_{0}-\mathrm{V}\right)=-\mathrm{kt}-\mathrm{C} \\
& \mathrm{V}_{0}-\mathrm{V}=\mathrm{e}^{-\mathrm{kt}} \mathrm{e}^{-\mathrm{C}} \\
& \mathrm{V}=\mathrm{V}_{0}-\mathrm{e}^{-\mathrm{kt}} \mathrm{e}^{-\mathrm{C}}
\end{aligned}
$$

Ketika kita memasukkan syarat awal tadi:

$$
0=\mathrm{V}_{0}-\mathrm{e}^{-0} \mathrm{e}^{-\mathrm{C}}
$$

Nilai $\mathrm{C}$ dapat diperoleh yakni:

$$
\mathrm{e}^{-\mathrm{C}}=\mathrm{V}_{0}
$$

Kemudian persamaan (9) dicelupkan ke dalam persamaan (8) guna memperoleh:

$$
\begin{aligned}
& \mathrm{V}=\mathrm{V}_{0}-\mathrm{e}^{-\mathrm{kt}} \mathrm{V}_{0} \\
& \mathrm{~V}=\mathrm{V}_{0}\left(1-\mathrm{e}^{-\mathrm{kt}}\right)
\end{aligned}
$$

Gambar berikut adalah contoh kurva perubahan volume kopi yang meresap ke dalam biskuit sebagai fungsi waktu. Mulanya kopi meresap cepat sehingga volume bertambah cepat. Setelah cukup lama, kopi meresap sedikit demi sedikit sehingga pertambahannya menjadi sangat lambat.

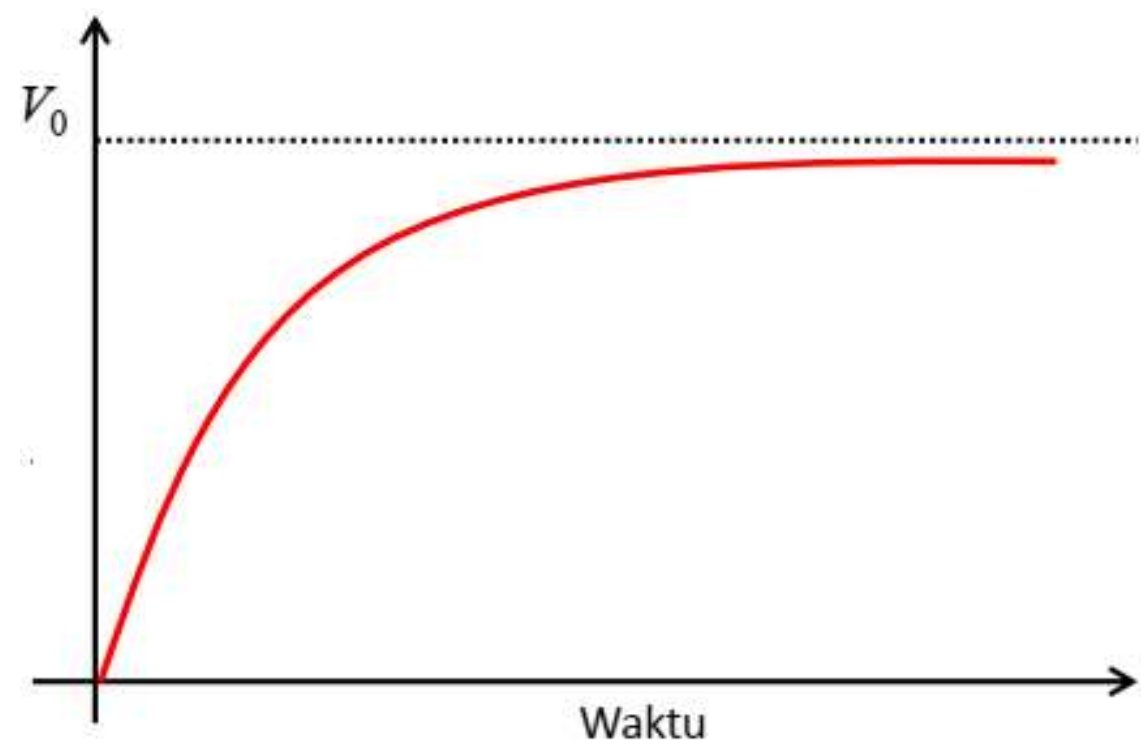

